\title{
PENENTUAN COLLATERAL COVERAGE RATIO (CCR) SUATU PERUSAHAAN DENGAN MENGGUNAKAN FINANCIAL RATIO COVENANTS
}

\author{
Sheren Danella Jieandy dan Ignatius Rony Setyawan \\ Program Studi Manajemen Fakultas Ekonomi \& Bisnis \\ Universitas Tarumanagara \\ Email: sherendj@gmail.com
}

\begin{abstract}
The purpose of this research is to investigate the influence of Current Ratio, Debt To Equity Ratio, and Company Size to Collateral Coverage Ratio (CCR) at registered company. The sample used in this research consists 100 companies that listed on the Indonesia Stock Exchange. The sampling method is non probability sampling with the sampling technique using purposive sampling. The analysis is performed by using the Panel Data regression analysis by the Fixed Effects Model in testing the hypothesis. The results show that Debt To Equity Ratio (DER) have a positive effect on Collateral Coverage Ratio (CCR) while Current Ratio CR) and Company Size (SIZE) have a negative effect on Collateral Coverage Ratio (CCR)
\end{abstract}

Keywords: CR, DER, SIZE, CCR

\begin{abstract}
Abstrak: Tujuan penelitian ini adalah untuk mengetahui pengaruh Current Ratio, Debt To Equity Ratio, dan SIZE terhadap risiko kredit Collateral Coverage Ratio (CCR) pada perusahaan yang terdaftar. Sampel yang digunakan dalam penelitian ini terdiri dari 100 Perusahaan yang terdaftar pada Bursa Efek Indonesia. Metode pengambilan sampel yang digunakan yaitu non probability sampling dengan teknik pengambilan sampel menggunakan purposive sampling. Analisis dilakukan dengan menggunakan Analisis Regresi Data Panel dengan Fixed Effect model dalam pengujian hipotesis. Hasil menunjukkan bahwa Debt To Equity Ratio (DER) berpengaruh positif terhadap Collateral Coverage Ratio (CCR) sedangkan Current Ratio (CR) dan Ukuran Perusahaan (SIZE) berpengaruh negatif terhadap Collateral Coverage Ratio (CCR).
\end{abstract}

Kata Kunci: CR, DER, SIZE, CCR

\section{LATAR BELAKANG}

Risiko kredit merupakan salah satu hal yang tidak bisa dihindari walaupun sudah melakukan analisis sebelumnya. Maka dari itu, munculah jaminan yang perlu disiapkan karena pinjaman apapun merupakan risiko bagi kreditur. Jaminan dapat digunakan kreditur untuk mengurangi segala kerugian yang mungkin akan dihadapinya karena debitur ternyata tidak mampu untuk melunasi hutangnya. Dengan adanya jaminan/agunan ini akan meminimalisir kerugian yang dialami kreditur atau sebagai kata lain, jaminan/agunan ini dapat digunakan oleh kreditur sebagai salah satu bentuk keamanan dalam kasus gagal bayar.

Kreditur memang berbisnis dalam memberikan pinjaman, tetapi mereka juga perlu untuk memitigasi risiko mereka, maka dari itu jaminan diperlukan untuk dilikuidasi jika wanprestasi terjadi. Tetapi, walaupun sudah dibuat perjanjian jaminan untuk kredit yang diberikan, tidak menutup kemungkinan bahwa jaminan tidak dapat menutupi $100 \%$ atas hutangnya. Maka dari itu, jaminan/agunan ini juga mempunyai risiko agunan (collateral 
risk). Risiko agunan ini merupakan kerugian biaya yang perlu kreditur tanggung dikarenakan nilai agunan tidak dapat menutup seluruh kredit macet. Untuk mengukur risiko tersebut, maka dibutuhkan perhitungan Collateral Coverage Ratio (CCR) dimana jika nilai yang dihasilkan besar akan semakin baik dan debitur dapat kesempatan pinjaman yang lebih besar. Begitu sebaliknya jika nilai Collateral Coverage Ratio (CCR) kecil. Adapun faktor yang mungkin memengaruhi Collateral Coverage Ratio ini seperti Current Ratio (CR), Debt To Equity Ratio (DER), dan juga Ukuran Perusahaan (SIZE).

\section{KAJIAN TEORI}

Menurut Jusuf (2014), nilai CCR atau Collateral Coverage Ratio yang dihasilkan setidaknya $100 \%$ yang artinya agunan yang diberikan mampu untuk membayar pinjaman pokok saja, tidak termasuk tunggakan bunga, denda, dan lain sebagainya. Di dalam melakukan perhitungan atas Collateral Coverage Ratio bukan hanya memperhitungkan tentang berapa nilai agunan yang diberikan atas hutang kredit yang didapatkan. Beberapa faktor internal di dalam perusahaan yang perlu untuk dilihat apakah juga akan berpengaruh terhadap CCR atau tidak seperti contohnya Current Ratio, Debt To Equity Ratio, dan juga Ukuran Perusahaan.

Menurut Kasmir (2018:134), apabila hasil dari perhitungan Current Ratio ini rendah, dapat dikatakan bahwa nasabah/perusahaan yang mendapatkan kredit dari bank itu kurang modal untuk membayar utang sehingga akan meningkatkan kegagalan dalam membayar kewajibannya. Berbeda dengan Debt To Equity Ratio yang dikatakan oleh Kasmir (2018:158), semakin besar nilainya maka akan semakin tidak aman keuangannya untuk membayar setiap hutang-hutangnya dan membuat bank tidak dengan mudah memberikan pinjaman.

Al-Smadi dan Ahmad (2010) menyatakan bahwa perusahaan besar yang terjaga nama baiknya akan disetujui dengan mudah oleh bank ketika perusahaan tersebut melakukan peminjaman kredit.

Penelitian sebelumnya yang dilakukan oleh Dimitris Gavalas \& Theodore Syriopoulos yang menemukan bahwa DER menjadi faktor yang penting yang diperlukan oleh bank dalam memutuskan kredit yang akan diberikan.

Penelitian yang dilakukan oleh Yang Yang juga menunjukkan bahwa hubungan agunan dan audit yang dianggap bank berkualitas tinggi dapat mencegah risiko kredit.

Berdasarkan kajian teori yang telah disebutkan dan hubungan antara variabel maka kerangka pemikiran dapat digambarkan sebagai berikut:

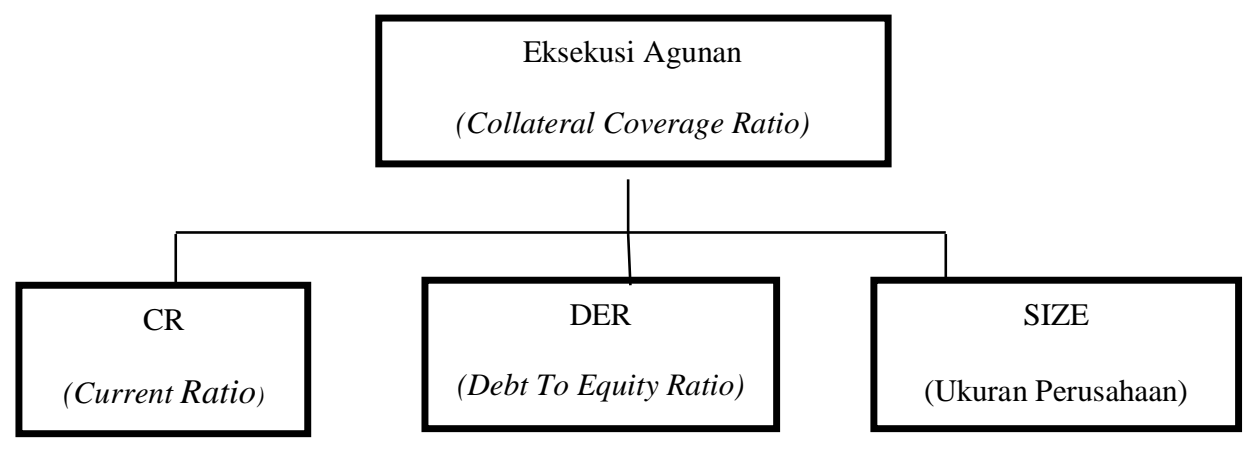

Gambar 1. Kerangka Pemikiran 

berikut:

Berdasarkan kerangka pemikiran diatas, dapat dirumuskan hipotesis penelitian sebagai

H1 : Current Ratio (CR) memiliki pengaruh signifikan terhadap Collateral Coverage Ratio (CCR).

H2 : Debt To Equity ratio (DER), memiliki pengaruh signifikan terhadap Collateral Coverage Ratio (CCR)

H3 : Ukuran Perusahaan (SIZE) memiliki pengaruh signifikan terhadap Collateral Coverage Ratio (CCR).

H4 : Current Ratio (CR), Debt To Equity Ratio (DER), Ukuran Perusahaan (SIZE), secara simultan memiliki pengaruh signifikan terhadap Collateral Coverage Ratio (CCR)

\section{METODOLOGI}

Di dalam penelitian ini, objek penelitian yang diteliti adalah Collateral Coverage Ratio (CCR) sebagai variabel dependen (terikat), sedangkan variabel independen (bebas) yang dilakukan di dalam penelitian ini adalah Current ratio (CR), Debt to Equity Ratio (DER), dan Ukuran perusahaan (SIZE). Populasi dari penelitian ini adalah perusahaan yang terdaftar di dalam Bursa Efek Indonesia (BEI) sampai dengan halaman 55. Metode pengambilan sampel penelitian adalah teknik purposive sampling dimana penelitian ini mengambil sampel perusahaan yang terdaftar di BEI pada periode 2009-2018 sampai dengan halaman 55 yang laporan keuangannya memenuhi kategori penelitian. Kriteria pemilihan sampel adalah: 1) perusahaan yang terdaftar di Bursa Efek Indonesia (BEI) pada periode 2009-2018. 2) perusahaan yang melakukan kredit terhadap bank. 3) perusahaan yang menggunakan kredit jangka panjang dengan agunan. Data yang digunakan di dalam penelitian ini adalah data sekunder yang peneliti peroleh dari laporan keuangan yang disediakan di situs website resmi Bursa Efek Indonesia (BEI) yaitu www.idx.co.id dan juga situs website resmi di setiap perusahaan yang terkait.

1. Collateral Coverage Ratio atau yang biasa disingkat menjadi CCR, adalah suatu variabel yang diukur dengan membagikan nilai aset tetap yang dimiliki oleh perusahaan dengan kewajiban jangka panjangnya.

$$
\text { Collateral Coverage Ratio }=\frac{\text { Fixed Asset }}{\text { Long Term Liabilities }}
$$

2. Current Ratio menurut Athanasius (2012:69) merupakan suatu rasio lancar yang menjadi rasio paling umum digunakan dalam hal mengukur tingkat likuiditas dari suatu perusahaan. Sutrisno (2009:216), mengatakan bahwa perhitungan dari current ratio adalah dengan membandingkan antara aktiva yang dimiliki perusahaan dengan hutang jangka pendek yang dimilikinya.

$$
\text { Current Ratio }=\frac{\text { Current Assets }}{\text { Current Liabilities }}
$$

3. Debt to Equity Ratio merupakan suatu rasio yang dapat digunakan oleh bank untuk menilai batasan kemampuan dari perusahaan dalam hal meminjam uang (Darsono dan Ashari, 2010:54-55). Debt to Equity Ratio diukur dengan membandingkan total hutang dengan total ekuitas. 


$$
\text { DER }=\frac{\text { Total Debt }}{\text { Total Equity }}
$$

4. Ukuran Perusahaan (SIZE) diukur dengan Logaritma Natural dari Total Asset.

$$
S I Z E=\operatorname{Ln}(\text { Total Asset })
$$

Data yang digunakan merupakan gabungan antara data time series dan data cross section yaitu analisis regresi data panel. Dalam menentukan model estimasi yang paling sesuai digunakan dalam data panel, maka dilakukan beberapa uji asumsi yaitu uji Chow, dan uji Hausman. Dikarenakan penggunaan data panel maka uji asumsi klasik yang digunakan adalah uji multikolinearitas untuk mengetahui apakah model regresi dalam penelitian terbebas dari multikolinearitas.

\section{HASIL ANALISIS DATA}

Pengujian hipotesis dalam penelitian ini dilakukan melalui analisis regresi data panel. penelitian ini menggunakan sampel dari 100 perusahaan untuk 5 periode yaitu semester 1 pada tahun 2017 sampai dengan semester 1 pada tahun 2019 yang menghasilkan 500 pengamatan. Model regresi yang digunakan dalam penelitian ini ditentukan berdasarkan hasil uji Chow dan Hausman apakah Fixed Effect Model atau Random Effect Model yang dilakukan dengan menggunakan software Eviews 10.

Tabel 1. Uji Chow

\begin{tabular}{lccc} 
Redundant Fixed Effects Tests & & & \\
Equation: Untitled & & & \\
Test cross-section fixed effects & Statistic & d.f. & Prob. \\
\hline \hline Effects Test & & & \\
\hline \hline Cross-section F & 14.025909 & $(99,397)$ & 0.0000 \\
Cross-section Chi-square & 751.776930 & 99 & 0.0000
\end{tabular}

Sumber: Hasil dari pengolahan data dengan Eviews 10.

Uji Chow atas data penelitian yang sudah dikumpulkan menunjukkan bahwa probabilitas cross-section chi square adalah 0,0000 yang berarti lebih kecil daripada 0,05. Maka atas uji Chow ini, model regresi yang baik digunakan adalah Fixed Effect Model. 
Tabel 2. Uji Hausman

Correlated Random Effects - Hausman Test

Equation: Untitled

Test cross-section random effects

Test Summary

Chi-Sq. Statistic

Chi-Sq. d.f.

Prob.

Cross-section random

129.756037

0.0000

Sumber: Hasil dari pengolahan data dengan Eviews 10.

Uji selanjutnya, uji Hausman menghasilkan probabilitas cross section random adalah 0,0000 yang berarti kurang dari 0,05. Maka dapat disimpulkan bahwa penelitian ini lebih tepat menggunakan model regresi Fixed Effect Model.

Tabel 3. Regresi Linier Berganda

Dependent Variable: CCR

Method: Panel Least Squares

Date: 02/07/20 Time: 11:33

Sample: 2017S1 2019S1

Periods included: 5

Cross-sections included: 100

Total panel (balanced) observations: 500

\begin{tabular}{ccccc}
\hline \hline Variable & Coefficient & Std. Error & t-Statistic & Prob. \\
\hline \hline C & 7.114578 & 4.645710 & 1.531430 & 0.1265 \\
CR & -0.001382 & 0.518376 & -0.002666 & 0.9979 \\
DER & 0.479755 & 0.041528 & 11.55249 & 0.0000 \\
SIZE & -0.116689 & 0.190573 & -0.612309 & 0.5407 \\
\hline
\end{tabular}

Effects Specification

Cross-section fixed (dummy variables)

\begin{tabular}{llll}
\hline \hline R-squared & 0.778726 & Mean dependent var & 4.846670
\end{tabular}


Sheren dan Ignatius: Penentuan Collateral Coverage Ratio (CCR)...

Adjusted R-squared
S.E. of regression
Sum squared resid
Log likelihood
F-statistic
Prob(F-statistic)

Adjusted R-squared

Prob(F-statistic)

$\begin{array}{clc}0.721874 & \text { S.D. dependent var } & 15.00328 \\ 7.912372 & \text { Akaike info criterion } & 7.156060 \\ 24854.43 & \text { Schwarz criterion } & 8.024270 \\ -1686.015 & \text { Hannan-Quinn criter. } & 7.496744 \\ 13.69758 & \text { Durbin-Watson stat } & 3.115821\end{array}$

0.000000

Sumber: Hasil dari pengolahan data dengan Eviews 10.

Dari tabel 1 diatas, menunjukkan bahwa Debt To Equity Ratio (DER) berkolerasi positif terhadap Collateral Coverage Ratio (CCR). Sementara itu, Current Ratio (CR) dan Ukuran Perusahaan (SIZE) ditemukan berkolerasi negatif terhadap Collateral Coverage Ratio (CCR). Dapat dilihat bahwa probabilitas (F-statistic) $0.000000<0,05$ maka variabel Current Ratio (CR), Debt To Equity ratio (DER), Ukuran Perusahaan (SIZE) berpengaruh secara simultan/bersamaan terhadap Collateral Coverage Ratio (CCR). Hasil pengujian ini sesuai dengan hipotesis kelima yang diajukan dalam penelitian yaitu Current Ratio (CR), Debt To Equity Ratio (DER), Ukuran Perusahaan (SIZE) secara simultan memiliki pengaruh signifikan terhadap Collateral Coverage Ratio (CCR). Oleh karena itu, hipotesis kelima diterima.

Walaupun berpengaruh secara simultan, berdasarkan uji t, Current Ratio menunjukkan nilai koefisien sebesar $-0,001382$ dengan nilai probabilitas sebesar $0.9979>0,05$. Hal ini menunjukkan bahwa Current Ratio memiliki pengaruh yang negatif dan tidak signifikan terhadap Collateral Coverage Ratio. Hasil pengujian ini tidak sesuai dengan hipotesis pertama yang diajukan dalam penelitian yaitu Current Asset memiliki pengaruh signifikan terhadap Collateral Coverage Ratio (CCR). Maka, hipotesis pertama ditolak.

Debt To Equity ratio menunjukkan nilai koefisien sebesar 0.479755 dengan nilai probabilitas sebesar $0.0000<0,05$. Hal ini menunjukkan bahwa Debt To Equity ratio memiliki pengaruh yang positif dan signifikan terhadap Collateral Coverage Ratio. Hasil pengujian ini sesuai dengan hipotesis kedua yang diajukan dalam penelitian yaitu Debt To Equity ratio memiliki pengaruh signifikan terhadap Collateral Coverage Ratio (CCR). Maka, hipotesis kedua diterima. Hal ini dapat mendukung penelitian sebelumnya yang dilakukan oleh Dimitris Gavalas \& Theodore Syriopoulos yang menemukan bahwa DER menjadi faktor yang penting yang diperlukan oleh bank dalam memutuskan kredit yang akan diberikan.

Ukuran Perusahaan (SIZE), menunjukkan nilai koefisien sebesar -0.116689 dengan nilai probabilitas sebesar $0.5407>0,05$. Hal ini menunjukkan bahwa Ukuran Perusahaan memiliki pengaruh yang negatif dan tidak signifikan terhadap Collateral Coverage Ratio. Hasil pengujian ini tidak sesuai dengan hipotesis ketiga yang diajukan dalam penelitian yaitu Ukuran Perusahaan (SIZE) memiliki pengaruh signifikan terhadap Collateral Coverage Ratio (CCR). Maka, hipotesis ketiga ditolak.

Berdasarkan hasil tabel diatas juga dapat dilihat bahwa nilai Adjusted $\mathrm{R}^{2}$ adalah sebesar 0,721874 atau $72,19 \%$ yang berarti sebesar 72,19\% variabel CCR dapat dijelaskan oleh Current Ratio (CR), Debt To Equity ratio (DER), Ukuran Perusahaan (SIZE) dan sisanya sebesar $27,81 \%$ dapat dijelaskan oleh variabel lain. 


\section{Diskusi}

Berdasarkan hipotesis pertama menemukan bahwa Current Ratio memiliki pengaruh yang negatif dan tidak signifikan terhadap Collateral Coverage Ratio perusahaan yang terdaftar di BEI pada periode 2009-2018 dan melakukan kredit terhadap bank dengan agunan. Hal ini mengindikasikan semakin tinggi nilai Current Ratio yang dimiliki oleh suatu perusahaan, menyebabkan penurunan terhadap nilai Collateral Coverage Ratio. Current Ratio tidak berpengaruh dalam perhitungan Collateral Coverage Ratio.

Berdasarkan hipotesis kedua menemukan bahwa Debt To Equity ratio memiliki pengaruh yang positif dan signifikan terhadap Collateral Coverage Ratio perusahaan yang terdaftar di BEI pada periode 2009-2018 dan melakukan kredit terhadap bank dengan agunan. Hal ini mengindikasikan semakin tinggi nilai Debt To Equity ratio yang dimiliki oleh suatu perusahaan, menyebabkan kenaikan terhadap Collateral Coverage Ratio. Hasil penelitian ini menunjukkan bahwa perusahaan dengan nilai Debt To Equity Ratio cenderung memengaruhi nilai Collateral Coverage Ratio. Maka semakin tinggi DER yang dimiliki oleh suatu perusahaan, maka harus semakin besar pula nilai Collateral Coverage Rationya.

Berdasarkan hipotesis ketiga menemukan bahwa Ukuran Perusahaan memiliki pengaruh yang negatif dan tidak signifikan terhadap Collateral Coverage Ratio perusahaan yang terdaftar di BEI pada periode 2009-2018 dan melakukan kredit terhadap bank dengan agunan. Hal ini mengindikasikan semakin besar Ukuran dari suatu perusahaan, menyebabkan penurunan terhadap Collateral Coverage Ratio. Hasil penelitian menunjukkan bahwa perusahaan yang besar tidak berpengaruh dalam nilai Collateral Coverage Ratio karena perusahaan yang besar dipercaya mampu untuk melunasi hutang kreditnya.

Berdasarkan hipotesis keempat menemukan bahwa Current Ratio (CR), Debt To Equity Ratio (DER), Ukuran Perusahaan (SIZE) secara simultan memiliki pengaruh signifikan terhadap Collateral Coverage Ratio (CCR).

\section{KESIMPULAN}

Bagi pembaca yang ingin melakukan penelitian lebih lanjut dari penelitian ini dapat disarankan untuk menambah variabel independen lain yang dapat mempengaruhi Collateral Risk ini sehingga dapat menghasilkan hasil yang lebih akurat. Dapat menggunakan perusahaan-perusahaan yang lebih lama terdaftar di BEI, yang melakukan kegiatan kredit dengan agunan tertentu, yang melakukan kegiatan kredit selain dengan bank, dan lain-lain. Disarankan juga dapat meneliti dengan perusahaan pada sektor tertentu misalnya manufaktur saja, atau yang lainnya sehingga cakupan penelitian dapat menjadi lebih optimal. Untuk menggambarkan kondisi jangka panjang perusahaan diharapkan menggunakan periode penelitian diatas dari penelitian ini.

\section{DAFTAR RUJUKAN/PUSTAKA}

Al-Smadi, M.O. dan N.H. Ahmad. (2010). Factors Affecting Bank's Credit Risk : Evidence from Jordan. Working Paper. Second International Conference on Arab-Malaysian Islamic Global Business and Entrepreneurship. Yarmouk University and Damascus University.

Athanasius, Thomas. 2012. Berinvestasi Saham. Jakarta: PT. Elex Media Komputindo.

Dharsono \& Ashari. 2010. Pedoman Praktis Memahami Laporan Keuangan. Indonesia: Andi.

Gavalas, Dimitris., Theodore syriopoulus., 2014. An Integrated Credit Rating and Loan quality Model: Application To Bank Shipping Finance. University of Aegean. Audencia School of Management. France. 
Jusuf, Jopie.2014. Analisis Kredit Untuk Credit (Account) Ofiicer. Jakarta: Gramedia Pustaka Utama.

Kasmir.2018. Analisis Laporan Keuangan. Indonesia: Rajagrafindo Persada.

Pramana Putra, Wayan Ramantha.2015.Pengaruh Profitabiilitas, Umur Perusahaan, Kepemilikan Institusional, Komisaris Independen, dan Komite Audit Pada Ketepatwaktuan Publikasi Laporan Keuangan Tahunan. Jurnal Akuntansi Universitas Udayana.

Sutrisno. (2009), Manajemen Keuangan Teori, Konsep dan Aplikasi, Edisi Pertama Cetakan Ketujuh, Penerbit Ekonisia, Yogyakarta

Yang. 2014._Does high-quality auditing decrease the use of collateral?. China Journal of Accounting Research.Zhongnan University of Economics and Law.

https://www.fundera.com/blog/collateral-coverage-ratio-definition 